\title{
Isolation of equine endothelial cells and life cell angiogenesis assay ${ }^{1}$
}

\author{
Kathrin Dietze*, Ilka Slosarek, Tania Fuhrmann-Selter, Carsten Hopperdietzel, \\ Johanna Plendl and Sabine Kaessmeyer \\ Department of Veterinary Medicine, Institute for Veterinary Anatomy, Freie Universität Berlin, Germany
}

\begin{abstract}
Arterial or venous thromboses are frequent clinical complications with the risk of fatal progression. Recent studies suggest the disruption of angiogenesis in the course of thrombus resolution as the underlying pathomechanism.

Very similar to the situation in human patients, equine vessels have been described to be particularly susceptible to thrombosis. In contrast to humans, equine donors are readily available to obtain organs and tissues for isolation of endothelial cells.

Objective of this study was to isolate equine endothelial cells and develop an angiogenesis assay from primary cultures.

Macrovascular endothelial cells were obtained from jugular veins and carotid arteries of nine horses, one of which suffered from inflammatory processes. After enzymatic isolation, the cells were incubated in different selective primary media. Phenotypic identification of endothelial cells was accomplished by morphology and positive staining to von Willebrand factor. The reliable, inexpensive, and standardized combination of methods presented here resulted in pure endothelial cultures for angiogenesis assays that can be used in any cell culture laboratory.

Inverted phase microscopy and life cell imaging was used to characterize the stages of the angiogenic cascade of the endothelial cells. Life cell imaging gave new insights into the in vitro formation of capillary like structures including exocytosis of microparticles from endothelial cells before integration into the three-dimensional structure. We hypothesize that a specific population of endothelial cells showing a highly active migration pattern in life cell imaging might play a role in the resolution of thrombosis.
\end{abstract}

Keywords: Equine macrovascular endothelial cells, life cell imaging, angiogenesis assay, microparticles

\section{Introduction}

An early diagnosis of arterial or venous circulation disorders is paramount, since thrombosis is a frequently occurring clinical complication with an increased risk of heart and cerebrovascular disease or even death $[3,23]$. Various predisposing factors have been determined which trigger thrombosis manifestation including age [3], acute and chronical inflammatory processes [12, 40], malignancies [21], or hemorheological aspects, such as reduced plasma viscosity [6], repeated mechanical manipulations of peripheral vein catheters (venous side), or chemical properties of applied drugs [57]. In veterinary medicine, for different reasons thrombosis is seen less frequently than in human medicine, except for equine patients. Similar to human patients, horses often display severe vascular complications in the context of chronic inflammatory processes, especially after intravenous interventions $[17,32,35]$. In fact, equine vessels have been described to be more susceptible to chemical or mechanical manipulation

\footnotetext{
${ }^{1}$ Presented in part in abstract form at the Young Generation of Veterinary Anatomists Meeting in Leipzig, Germany, on July 2013.

${ }^{*}$ Corresponding author: Kathrin Dietze, Freie Universität Berlin, Institut für Veterinär-Anatomie, Koserstr. 20, 14195 Berlin,
} Germany. Tel.: +49 30838 53565; Fax: +49 30838 53480; E-mail: kathrin.dietze @ fu-berlin.de. 
than those of other species resulting in a hypercoagulation state in vivo [e.g., 30]. However, horses have not been considered as a model for human vasculature yet, even though, in contrast to human organs and tissues, samples from healthy equine donors are readily available, and pure endothelial cell strains derived from primary cell cultures can be established easily. It is well known that primary cell cultures and cell lines derived from primary cultures at low passages have many advantages over conventional cell lines, since they retain the closest similarity to phenotypic characteristics of endothelium in vivo [e.g., $49,61]$. Cell strains derived from primary cell cultures of healthy humans are rare, because for a variety of reasons it is difficult to gain access to organs and tissues for the isolation of endothelial cells.

Both in humans and equines, the pathohistological mechanism of thrombosis is initiated by mechanically or chemically induced lesions of the vascular endothelium, which lines the inner surface of all blood vessels. This is followed by adherence of platelets to the endothelial cells. Platelet adhesion causes enhanced secretion of inflammatory factors, which leads to infiltration of leukocytes into the vessel wall. Further recruitment of platelets at the site of the endothelial lesion and fibrin formation eventually result in coagulation and thrombosis $[1,57]$.

It is well known that vascular endothelial cells play an important mediatory role in the coagulative response to inflammation and thrombosis [53]. However, these cells also seem to participate in the resolution of thrombosis by building vascular channels into the fibrin clots [60]. Recent studies showed that thrombus resolution depends on endothelial cell differentiation and angiogenesis [2].

We hypothesize that the reason for deficient thrombolysis in the equine is ineffective angiogenesis due to mechanical or chemical lesion of endothelial cells. Thus, objective of this study was to isolate equine endothelial cells and develop an angiogenesis assay from primary cultures to demonstrate the assessment of each step of vascular development in vitro. In order to analyze details of individual and collective activities of vascular endothelial cells during angiogenic morphogenesis, living endothelial cells were examined during in vitro angiogenesis by life cell imaging. This technique allows monitoring of cell development over a long period of time, i.e. up to several weeks [e.g., 80], under constant environmental conditions. In addition, the cells can be examined in detail by employing time lapse microscopy.

\section{Material and methods}

\subsection{Sampling}

Samples of vessels from eight clinically healthy horses and one horse with gonarthritis and tarsal phlegmona on the hindlegs were obtained (Table 1) after the animals had been euthanized at the Institute for Veterinary Anatomy (Freie Universität Berlin) under veterinary control in accordance with all relevant local animal welfare laws and regulations. Samples of the left and right carotid arteries (Arteria carotis communis) and jugular veins (Vena jugularis externa) were harvested. In all horses, the left jugular vein was used for administering agents for euthanasia following sedation and general anesthesia.

\subsection{Histology of vessels}

Isolation of endothelial cells was carried out using an enzyme solution as described below. In order to ensure that only endothelial cells had been harvested, samples of each vessel were prepared for light microscopy before and after enzyme treatment. Samples were fixed in $4 \%$ buffered formalin for 24 hours, dehydrated in an ascending series of alcohol and embedded in paraffin. Subsequently, slides of 4-6 $\mu \mathrm{m}$ 
Table 1

List of horses the samples were obtained from

\begin{tabular}{|c|c|c|c|c|}
\hline & Gender & Age [yrs] & Breed & Samples \\
\hline horse 1 & $\sigma^{7}$ & 7 & pony & A. carotis communis sinistra \\
\hline horse 2 & $0^{7}$ & 0.75 & warmblood & A. carotis communis sinistra \\
\hline horse 3 & q & 20 & pony & A. carotis communis sinistra \\
\hline horse 4 & $\sigma^{7}$ castrated & 23 & warmblood & $\begin{array}{l}\text { A. carotis communis sinistra/dextra } \\
\text { V. jugularis externa sinistra/dextra }\end{array}$ \\
\hline horse 5 & q & 13 & pony & $\begin{array}{l}\text { A. carotis communis sinistra/dextra } \\
\text { V. jugularis externa sinistra/dextra }\end{array}$ \\
\hline horse 6 & $\sigma^{7}$ & 12 & pony & $\begin{array}{l}\text { A. carotis communis sinistra/dextra } \\
\text { V. jugularis externa sinistra/dextra }\end{array}$ \\
\hline horse 7 & $\sigma^{7}$ & 18 & pony & $\begin{array}{l}\text { A. carotis communis sinistra/dextra } \\
\text { V. jugularis externa sinistra/dextra }\end{array}$ \\
\hline horse 8 & $\sigma^{7}$ & 3.5 & pony & A. carotis communis sinistra \\
\hline horse 9 & $\sigma^{7}$ castrated & 17 & pony & $\begin{array}{l}\text { A. carotis communis sinistra/dextra } \\
\text { V. jugularis externa sinistra/dextra }\end{array}$ \\
\hline
\end{tabular}

were cut using a SM200R microtome (Leica, Wetzlar, Germany) followed by Weigert's Resorcin-Fuchsin staining as described elsewhere [71].

\subsection{Isolation of endothelial cells}

Samples of the vessels of $5 \mathrm{~cm}$ length were obtained antiseptically. After carefully cleaning the outside of the vessel with $70 \%$ ethanol, samples were submersed and rinsed in a plastic tube containing $50 \mathrm{ml}$ of sterile PBS (phosphate buffered saline, $4^{\circ} \mathrm{C}$, Serva, Heidelberg, Germany) adapted with antibiotics (10.000 U/ml penicillin, $10 \mathrm{mg} / \mathrm{ml}$ streptomycin, $5 \mathrm{mg} / \mathrm{ml}$ gentamicin) in order to remove the remaining blood. Vessels were then transferred to a new tube with PBS/antibiotics, stored on ice and transported to the laboratory.

All samples were processed in a laminar flow system under sterile conditions. After removal of fatty and connective tissue, the vessel segments were filled with prewarmed $\left(37^{\circ} \mathrm{C}\right)$ collagenase solution and incubated for 45 minutes until endothelial cells were detached. Then, the collagenase solution containing cells was decanted into $15 \mathrm{ml}$ tubes, gently mixed with $10 \mathrm{ml}$ of PBS/antibiotics and centrifuged at $200 \times \mathrm{g}$ for five minutes at room temperature. The pellet was resuspended in $15 \mathrm{ml} \mathrm{PBS/antibiotics} \mathrm{and} \mathrm{centrifuged}$ again. Next, the cells were resuspended in $3 \mathrm{ml}$ primary growth medium $\left(\mathrm{P}^{0}\right)$ and processed repeatedly through a Sterican needle (Sterican, $0.6 \times 30 \mathrm{~mm}$, Braun, Melsungen, Germany) in order to separate aggregated cell structures. Six-well plates were coated with $2 \mathrm{ml}$ of autoclaved $1.5 \%$ porcine gelatin Type A [Sigma-Aldrich, Taufkirchen, Germany] suspended in PBS at $37^{\circ} \mathrm{C}$ for 30 minutes. Subsequently, wells were loaded with $1.5 \mathrm{ml}$ cell suspension per well and incubated at $37^{\circ} \mathrm{C}$ with $5 \% \mathrm{CO}_{2}$ concentration and $98 \%$ relative humidity after the fluid had been removed. This last step of isolation was completed within two hours after sampling from the animals. After another two hours the medium was changed, removing most of the non-endothelial cells, which have less adhesion capacity than endothelial cells [38, 64].

When the cells had formed clonal islets of approximately 25 polygonal cells, they were scraped off using a cell scraper. Subsequently, cells of one islet were centrifuged in PBS/antibiotics and the pellet was 
Table 2

Solutions used for cell culture

DMEM+ Culture medium

$\mathrm{P}^{0}$ Primary medium

Enzyme solution for isolation of cells

S180 conditioned medium
$43.5 \mathrm{ml}$ Dulbecco's Modified Eagle Medium (DMEM containing $3.7 \mathrm{~g} / \mathrm{l} \mathrm{NaHCO} 3$; $4.5 \mathrm{~g} / \mathrm{l}$ D-glucose; low endotoxin) (Biochrom AG, Berlin)

$5 \mathrm{ml}$ FBS (Gibco/life technologies, Darmstadt) or FHS (biowest, Nuaillé, France)

$0.5 \mathrm{ml}$ L-glutamin $(200 \mathrm{mM})$ (Sigma-Aldrich, Taufkirchen)

$0.5 \mathrm{ml}$ gentamicin $(5 \mathrm{mg} / \mathrm{ml}$ ) (PromoCell $\mathrm{GmbH}$, Heidelberg)

$0.5 \mathrm{ml}$ penicillin/streptomycin $(10.000 \mathrm{U} / \mathrm{ml} / 10 \mathrm{mg} / \mathrm{ml})$ (Sigma-Aldrich,

Taufkirchen)

$32.5 \mathrm{ml}$ DMEM+

Conventional serum: $5 \mathrm{ml}$ FBS (Gibco/life technologies, Darmstadt)

Species-specific serum: FHS (biowest, Nuaillé, France)

$1 \mathrm{ml}$ ECGS (endothelial cell growth supplement from bovine neural tissue)

(Sigma-Aldrich, Taufkirchen)

$0.5 \mathrm{ml}$ penicillin/streptomycin $(10.000 \mathrm{U} / \mathrm{ml} / 10 \mathrm{mg} / \mathrm{ml})$ (Sigma-Aldrich,

Taufkirchen)

$0.5 \mathrm{ml}$ heparin sodium salt from porcine intestinal mucosa (Sigma-Aldrich, Taufkirchen)

$0.5 \mathrm{ml}$ BME vitamin $(100 \times)$ (Sigma-Aldrich, Taufkirchen)

$25 \mathrm{mg}$ Collagenase II from Clostridium histolyticum ( $\geq 125 \mathrm{CDU} / \mathrm{mg})$

(Sigma-Aldrich, Taufkirchen)

$25 \mathrm{mg}$ Collagenase IV from Clostridium histolyticum ( $\geq 125 \mathrm{CDU} / \mathrm{mg})$

(Sigma-Aldrich, Taufkirchen)

$9.8 \mathrm{ml}$ DMEM (Biochrom AG, Berlin)

$100 \mu 1$ NU-Serum IV Serum Replacements (BD Biosciences, Heidelberg)

$100 \mu l$ DNase solution (20.000 U/ml in H2O) (Sigma-Aldrich, Taufkirchen)

S180 mouse sarcoma cells were cultured in DMEM+medium. Used

cell-conditioned medium was removed, collected and filtrated using sterile syringe filters with pore size $22 \mu \mathrm{m}$ (Techno Plastic Products AG, Trasadingen Switzerland)

covered with $0.05 \%$ trypsin-EDTA $\left(37^{\circ} \mathrm{C}\right)($ Gibco/life technologies, Darmstadt, Germany). Alternately, several islands (up to 4 ) were pooled. After 2-3 minutes, $\mathrm{DMEM}^{+}$was added to stop trypsin action. The cells were centrifuged, and the pellet was resuspended in $500 \mu l \mathrm{P}^{0}$ medium. From these primary cells (passage 1), primary cell culture lines were established on gelatin coated 24-well plates. Medium was renewed every three to four days. For detailed information on chemicals and solutions see Table 2.

After cells of passage 1 had reached the subconfluent stage, they were trypsinized $(0.05 \%$ trypsinEDTA, $37^{\circ} \mathrm{C}$ ) and resuspended in $\mathrm{P}^{0}$. After expanding the cultures by another passaging, cells were processed in the third passage for all further examinations including:

1. identification and characterization by phase contrast and transmission electron microscopy

2. identification via immunocytochemistry

3. monitoring vascular development by phase contrast microscopy and life cell imaging

4. analysis of growth in different culture media 


\subsection{Phenotypic characterization and identification of cells}

Phenotype of the equine endothelial cells was examined by inverted phase microscopy (Zeiss Axiovert 25) and identified by staining with an antibody to von Willebrand Factor (vWF, Factor VIII) [42, 45, 55]. Transmission electron microscopy was used to examine ultrastructure and demonstrate presence of endothelial marker organelles, i.e. Weibel Palade bodies [87, 88].

For antibody staining, 3.000 cells of passage 3 were seeded on 96-well plates and kept in culture for defined time intervals. Subsequently, the cells were fixed in a 1:1 ice-cold acetone and methanol mixture and rinsed with distilled water and PBS. This was followed by treatment with blocking buffer containing $1.5 \% \mathrm{H}_{2} \mathrm{O}_{2}, 0.1 \%$ saponine, and $1 \%$ bovine serum albumin (BSA) in PBS. After washing with PBS and 3\% BSA, cells were processed with polyclonal rabbit anti-human vWF (Dako GmbH, Hamburg) as primary antibody with cross reactivity to equine cells. Cross reactivity is based on the conserved structure of equine and human genes with an identity of $87 \%$ of the nucleotid sequence coding for vWF (PubMed Basic Local Alignment Search Tool).

Buffer and buffered rabbit IgG fraction (Dako GmbH, Hamburg) were used as negative controls with protein concentrations used corresponding to antibody concentrations $(155 \mu \mathrm{g} / \mathrm{ml})$.

For transmission electron microscopy 10.000 cells were seeded on a 3470 polyester membrane (Corning, Wiesbaden, Germany) and cultured for 15 days. Culture medium was removed and substituted by PBS, followed by cacodylate buffer (0.1 M, pH 7.2) and Karnovsky's fixative (Merck Eurolab, Darmstadt, Germany). After 4 hours of refrigeration at $4{ }^{\circ} \mathrm{C}$, the cells were rinsed with cacodylate buffer and contrasted with cacodylate-buffered osmium tetroxide (1\%) for 2 hours at $4{ }^{\circ} \mathrm{C}$. Subsequently, the cells were dehydrated and embedded in epon via propylene oxide (Serva Electrophoresis, Marburg, Germany). Semi-thin sections $(0.8 \mu \mathrm{m})$ were evaluated to establish the appropriate specimen for ultra-thin sectioning (Ultracut, Reichert-Jung, Vienna, Austria). Slides of $70 \mathrm{~nm}$ were cut and absorbed to nickel grids, contrasted with lead citrate and uranyl acetate, and examined using an EM10CR electron microscope (Zeiss, Jena, Germany).

\subsection{Monitoring of vascular development of cells in vitro}

20.000 endothelial cells of passage 3 were seeded on 24-well plates. Over a time period of eight weeks, these cells were monitored and photographed at regular intervals to document stages of angiogenesis using a phase contrast microscope. Digital pictures of randomly chosen areas were taken with a video camera (Inteq 00061; Inteq, Berlin, Germany) using the image editing system Axiovision (Verison 3.0; Zeiss, Jena, Germany). Visual fields were standardized by taking pictures at the same magnification (100 $\mathrm{x})$ and the same area $\left(691200 \mu \mathrm{m}^{2}\right)$.

In addition, endothelial cells were monitored using an inverted Olympus IX 81 life cell imaging microscope (Olympus, Hamburg, Germany) with integrated climatization control. Cells were investigated in their native state without immunofluorescence labeling. The culture dishes were placed in a temperature-controlled chamber at $37^{\circ} \mathrm{C}$ with $5 \% \mathrm{CO}_{2}$ and about $50 \%$ humidity to prevent evaporation of the culture medium. The microscope was equipped with a monochrome cooled XM10 CCD camera (Olympus, Hamburg, Germany). Olympus Cell R software version 3.1 was used for image-acquisition (Olympus, Hamburg, Germany). Images were obtained using an Olympus UPLFLN phase-contrast with a $20 \times$ NA 0.45 objective. Original images were 16 bit grey scale with a resolution of $1.376 \times 1.032$ pixels. 
20.000 cells of passage 3 were seeded on 24-well plates. Endothelial cells were examined at defined intervals shown as a series combination of different focal planes (z-stack), and recorded in time-lapse mode. Different projections were used in a series to produce a single three-dimensional image.

Moreover, time-lapse live imaging of the cells was started on the 28th culturing day of the assay. Long-time sequences over 44 hours of these cells were documented at one frame every six minutes and also recorded in time-lapse mode. The medium was changed every three to four days until termination of the assay.

\subsection{Documentation of cellular proliferation and vascular development in different culture media}

To find the optimal medium for angiogenesis and capillary formation in vitro, cells were cultivated in different media containing conventional fetal bovine serum (FBS) and species-specific equine serum (fetal horse serum, FHS), either in S180-conditioned or unconditioned medium. For detailed information on chemicals and solutions see Table 2 .

\section{Results}

\subsection{Histology}

Weigert's Resorcin-Fuchsin staining of the vessel samples prior to and after collagenase treatment revealed that endothelial cells were removed evenly from the tunica intima of the vessels (Fig. 1). Even though the lamina elastica interna was clearly visible, especially in the sampled arteries, indicating an intact muscular layer, it cannot be ruled out that single cells other than endothelial cells, such as fibrocytes of the subendothelial layer or smooth muscle cells of the media, were harvested.

A

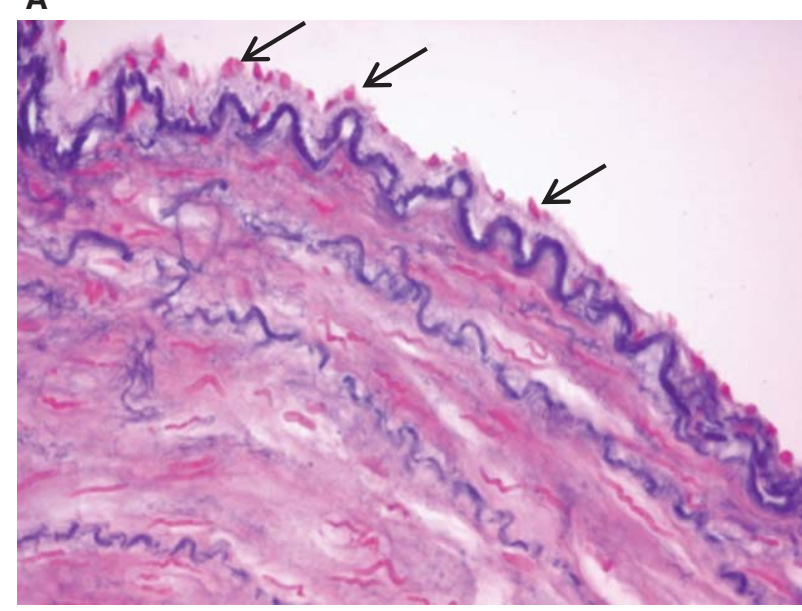

B

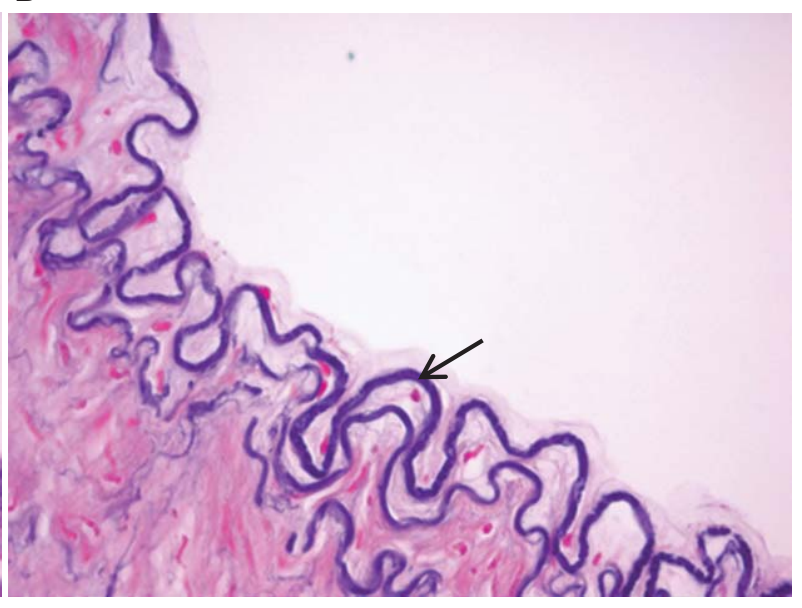

Fig. 1. Arteria carotis communis, Weigert's Resorcin-Fuchsin staining; A: cell nuclei of intact endothelium (arrows) prior to collagenase treatment; B: endothelium removed after collagenase treatment, lamina elastic interna (arrow); light microscopy, original magnification $400 \times$. 


\subsection{Primary cultures}

After two hours $50 \%$ of the cells of the primary cultures, seeded on 6-well plates in a density of approximately $4 \times 10^{4}$ cells, were adherent to the bottom of the culture plate (Fig. 2 ).

At this point in time, the primary cell cultures represented mixed populations of different cell species. Most of the cells were of polygonal shape. However, individual spindle shaped cells (which probably correspond to fibroblasts or smooth muscle cells) were observed (Fig. 3).

These cells were further separated from the polygonal ones at first passaging, when clonal islets of approximately 25 polygonal cells exclusively were carefully scraped off and seeded separately or pooled in a new gelatinized 24-well plate. These cells proliferated and formed colonies of 25-200 cells as seen in Fig. 4.

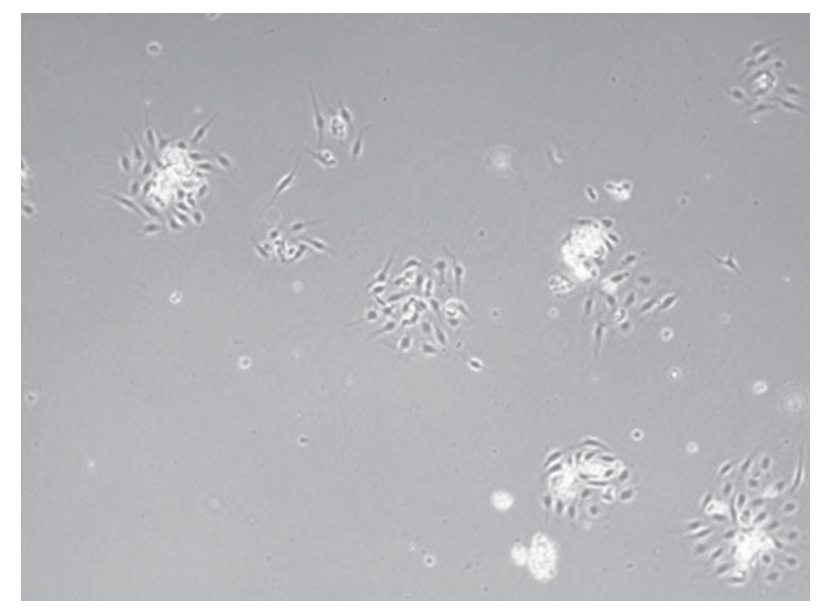

Fig. 2. Phase contrast microscopy of primary equine endothelial cells in vitro. After two hours in vitro, $50 \%$ of the cells were adherent at the bottom of the culture plate, original magnification $100 \times$.

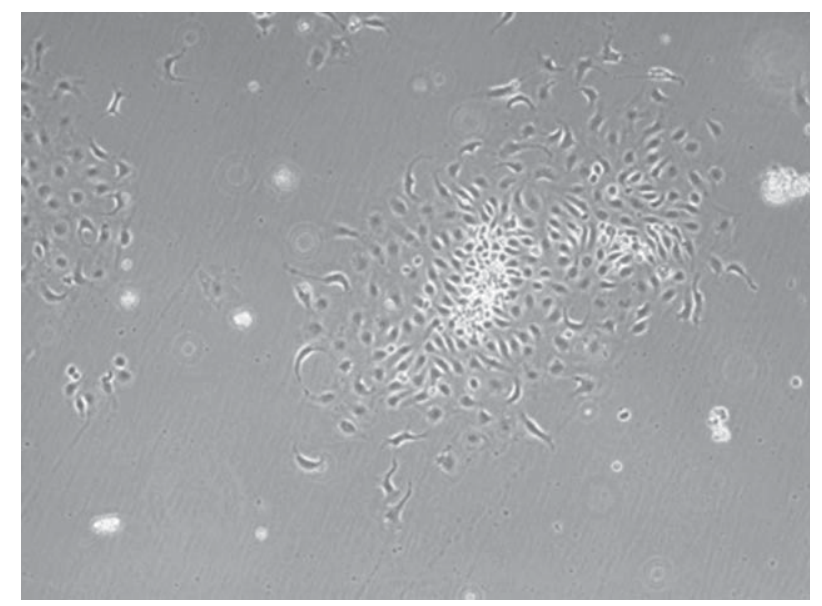

Fig. 3. Phase contrast microscopy of primary equine endothelial cells in vitro. Primary cell cultures with clonal islets; polygonal and spindle shaped cells are visible, original magnification $100 \times$. 


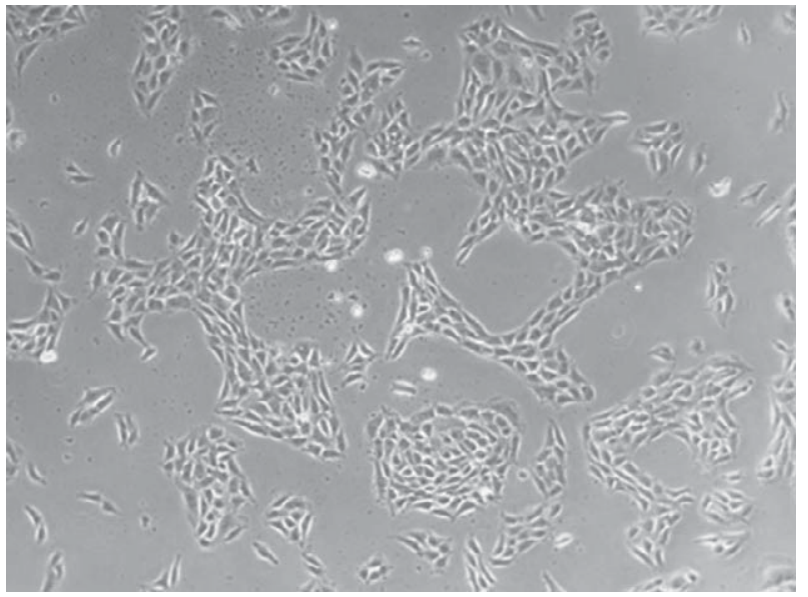

Fig. 4. Passage 2, phase contrast microscopy of endothelial cells derived from primary equine cells in vitro, original magnification $100 \times$

\subsection{Identification and characterization of equine endothelial cells}

In addition to the identification of cells via immunolabelling of endothelial markers and demonstration of endothelial marker organelles, the phenotype of equine endothelial cells was confirmed via phase contrast microscope in vitro. Cells contained a single nucleus, often with two nucleoli; surrounding cytoplasm appeared granular, cell membranes were clearly visible. Whereas the endothelial cells developed up to 4 fine protrusions in the subconfluent monolayer, they became roundish without projections upon confluency. In the confluent monolayer the cultures displayed the characteristic endothelial "cobblestone pattern". This also marked the start of the angiogenic cascade in the cultures. The population doubling time was ca. $48 \mathrm{~h}$.

\subsection{Ultrastructural characterization}

In most cells, the shape of nuclei was elongated and regular (Fig. 5). Up to nine electron dense roundish to rod-shaped tubular bodies were found to be located in the cytoplasm close to the outer cell membrane in one section of a cell (Fig. 6). These endothelial specific organelles, so-called Weibel-Palade bodies, were observed in many cells.

The endothelial cells also displayed certain other organelles, such as rough endoplasmatic reticulum and mitochondria of the crista type. Microvilli were present on the cellular surfaces. Intercellular contacts were formed by interdigitations of the outer cell membranes. Fibrillar material was located in the extracellular space and between the cellular membranes.

\subsection{Expression of the endothelial cell specific $v W F$}

Identification of the endothelial cells was also performed by immuno-localization of vWF. All cells of passage 3 cultures stained strongly positive for anti-vWF. Cells displayed distinct granular staining across their cytoplasma (Fig. 7). Until day 10 in vitro, the cell nucleus appeared to be stained stronger 


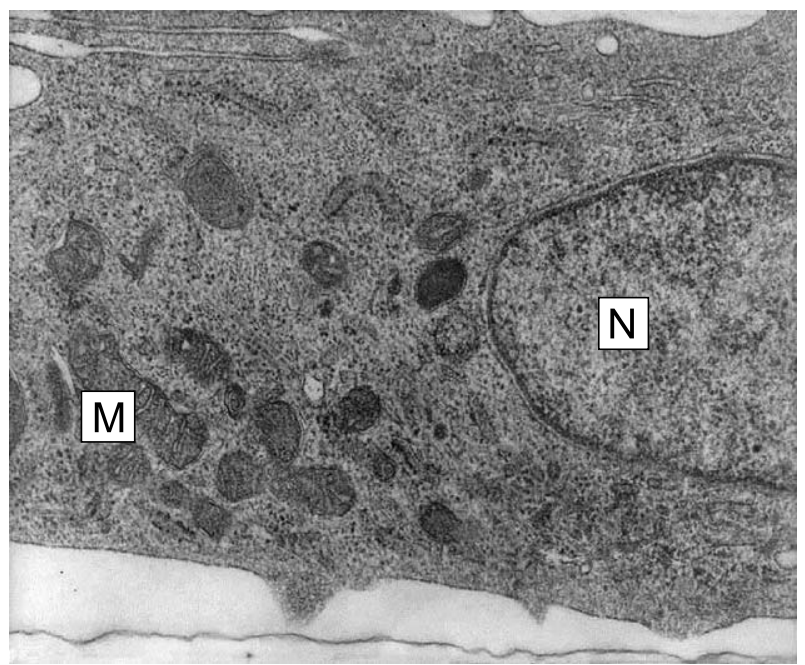

Fig. 5. Ultrastructure of primary equine endothelial cells. Regularly shaped nucleus $(\mathrm{N})$ and numerous organelles, especially mitochondria $(\mathrm{M})$, transmission electron microscopy, original magnification $25.000 \times$.

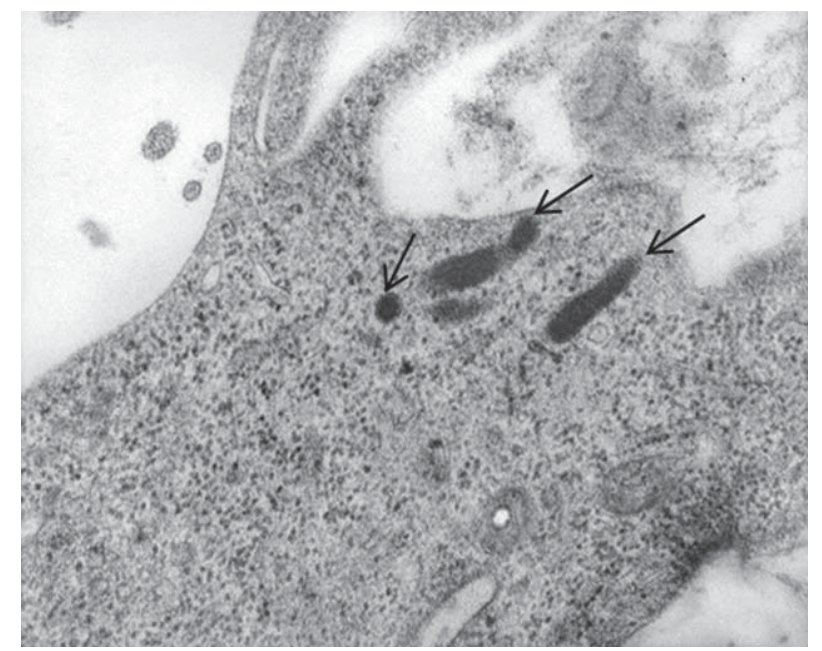

Fig. 6. Ultrastructure of primary equine endothelial cells. Weibel-Palade bodies (arrows) are located in the cytoplasm close to the outer cell membrane, transmission electron microscopy, original magnification $31.500 \times$.

than the cytoplasma. After 15 days, staining for vWF antibody of the endothelial cell cultures became weaker, but was still visible.

\subsection{Staging of development and morphology of capillary-like structures of equine endothelial cells in vitro}

In subsequent analyses, only cells that were positive for endothelial markers were included. Upon seeding, cells of passage 3 proliferated and formed roundish colonies of 10 to 20 polygonal cells. While 


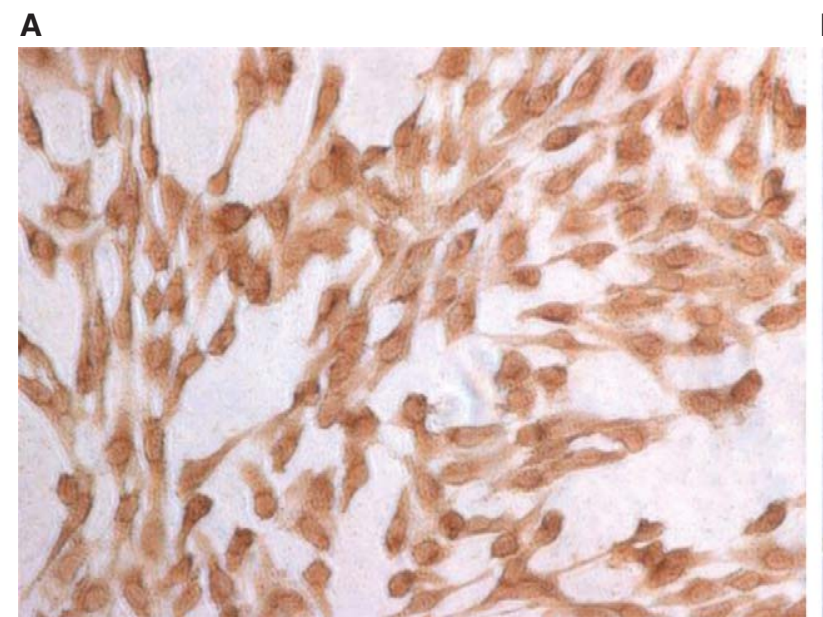

B

Fig. 7. Phase contrast microscopy of primary equine endothelial cells in vitro, light microscopy, original magnification $200 \times$. A: all cells of the passage 3 cultures stained strongly positive for anti-von Willebrand factor (vWF); B: negative control.

continuously proliferating, new cells at the edge of the colonies became longish and arranged linearly side by side. Thus, the shape of growing colonies changed and became elongated. Cells located at the tips of these elongated cellular islands developed cellular protrusions and pseudopodia and finally connected with similar cells of neighboring islands. Upon reaching confluency, cells regained their polygonal shape and a homogenous cobblestone-like monolayer covered $100 \%$ of the culture dish (stage 1 of the angiogenic cascade, Fig. 8A).

Upon confluency, sprouting was observed in certain areas of the culture dish. Single cells of the monolayer developed protrusions of 1-2 $\mu \mathrm{m}$ in size superimposing the monolayer. During further development, these cells proliferated and arranged themselves linearly side by-side, followed by the formation of planar, circular structures a few days later (stage 2 of the angiogenic cascade, Fig. 8B).

The circular cell structures connected and formed planar structures. Eventually, a distinct network consisting of single cell strands was present (stage 3 of the angiogenic cascade in vitro, Fig. 8C). A confluent monolayer still covered the culture dish.

In the following weeks, the linear endothelial strands transformed into three-dimensional capillary-like structures. At the same time, cell free areas appeared in the monolayer. In part, the capillary-like structures detached from the bottom of the culture well. The more cells were integrated into the cell-strands the more cell-free areas were detected. New cells appeared to integrate via pseudopodia formation into the network, which was attached to the bottom of the culture plate only in a few places. The cell-free areas of the network continued to increase in diameter by integration of an increasing number of cells. Finally, the endothelial cells displayed a three-dimensional configuration with a web-like pattern. Only about $20 \%$ of the endothelial cells remained on the bottom of the culture dish (stage 4 of the angiogenic cascade, Fig. 8D).

\subsection{Life cell imaging}

Life cell imaging allowed tracking of individual endothelial cells during in vitro angiogenesis. 
A

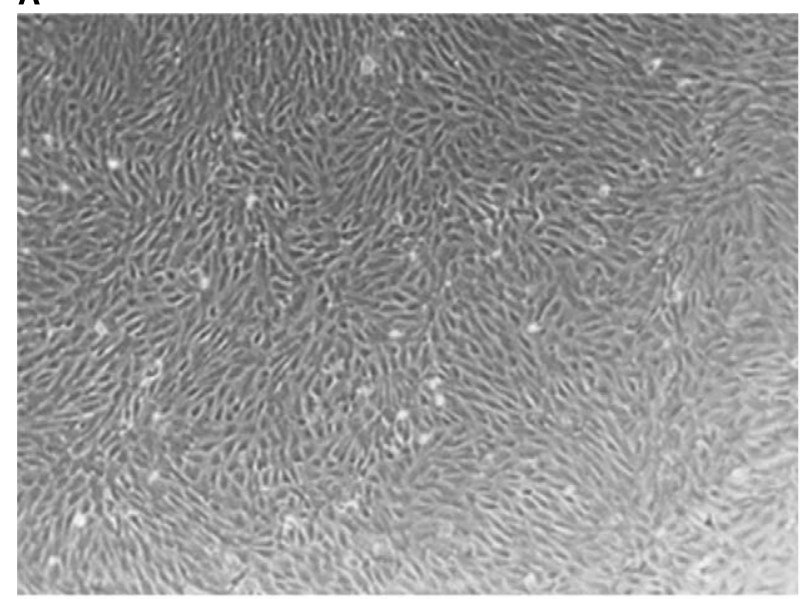

C

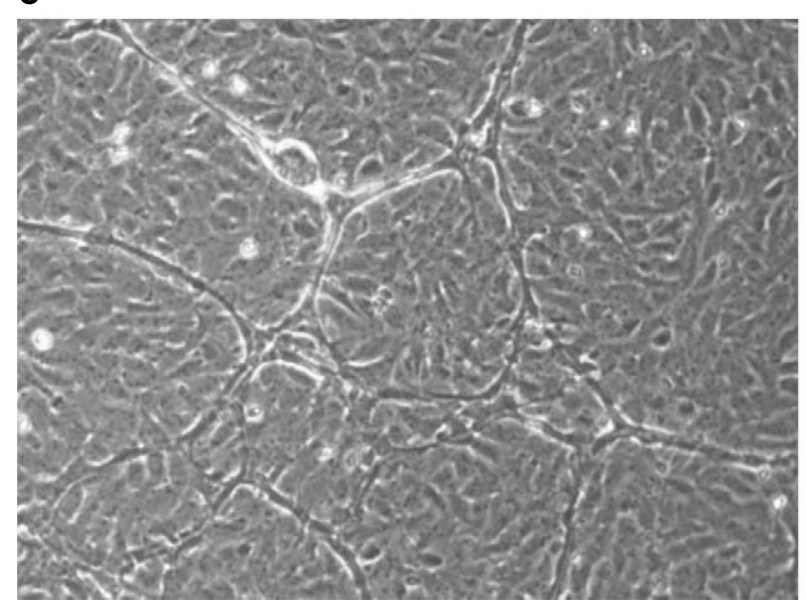

B

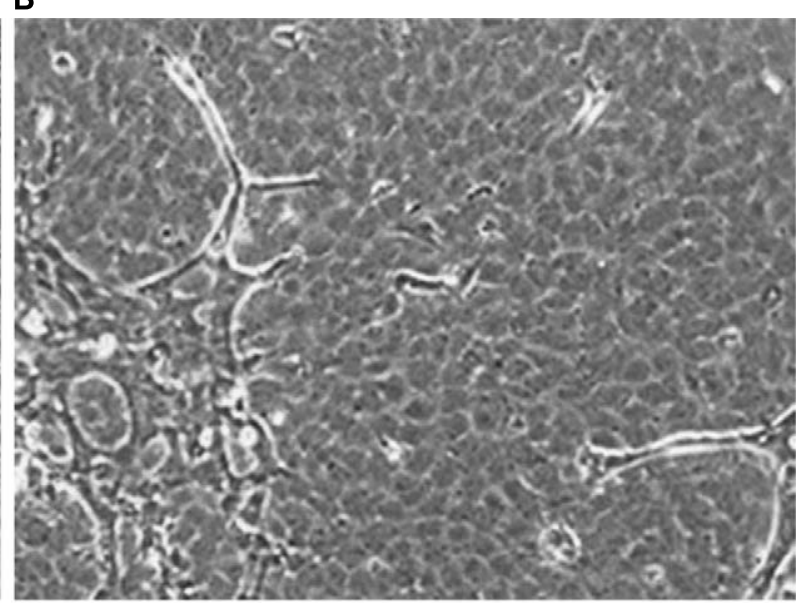

D

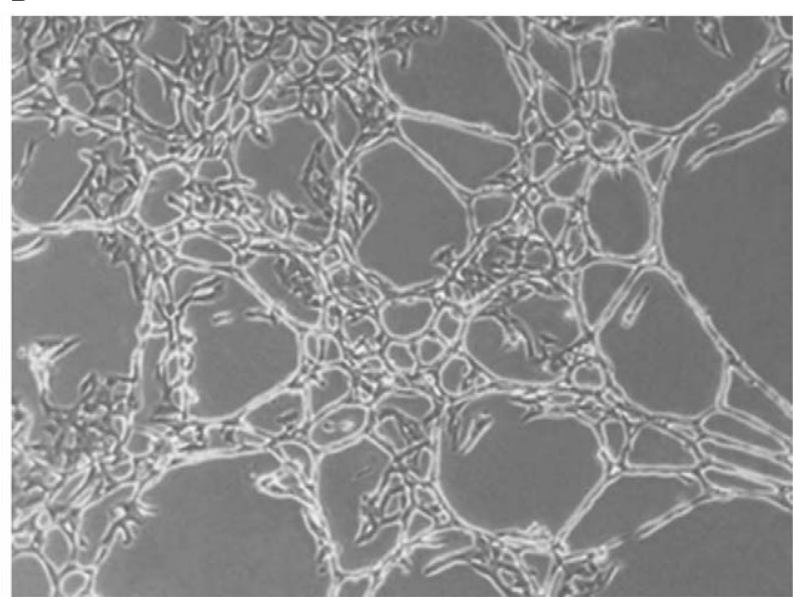

Fig. 8. Phase contrast microscopy of primary equine endothelial cells in vitro monitoring the angiogenesis cascade, original magnification 100×. (A) Stage 1, confluent monolayer. (B) Stage 2 of angiogenic cascade, individual cells of the monolayer developed protrusions; after linear side by-side arrangement, the cells formed planar, circular structures. (C) Stage 3, planar capillary-like structures and networking of single cell strands. (D) Stage 4, endothelial cells display a three-dimensional configuration.

Stage 1 of the angiogenesis cascade in vitro: Following mitotic proliferation cells formed a colony of ca. 10-20 cells. Before a confluent monolayer was formed, individual cells at the edges of the colonies developed protrusions of 1-2 $\mu \mathrm{m}$ in length. Subsequently, these cells started mitosis, i.e. they rounded up and lost adhesion to the colony. After the two daughter cells had been generated, they immediately re-developed cellular protrusions. With these, they contacted neighboring cells and either integrated themselves into the colony of origin or migrated towards neighboring colonies. Recurring contact to neighboring cells, particularly to those from different colonies, resulted in immediate mitosis. Frequently it could be observed that specific cells at the tip of the colonies detached themselves reversed their forward movement, and migrated back into the colony. Then, these cells moved through the whole length of the colony, thus passing a phalanx of 10 and more cells on each side. Certain tip cells returned to the cell 
A

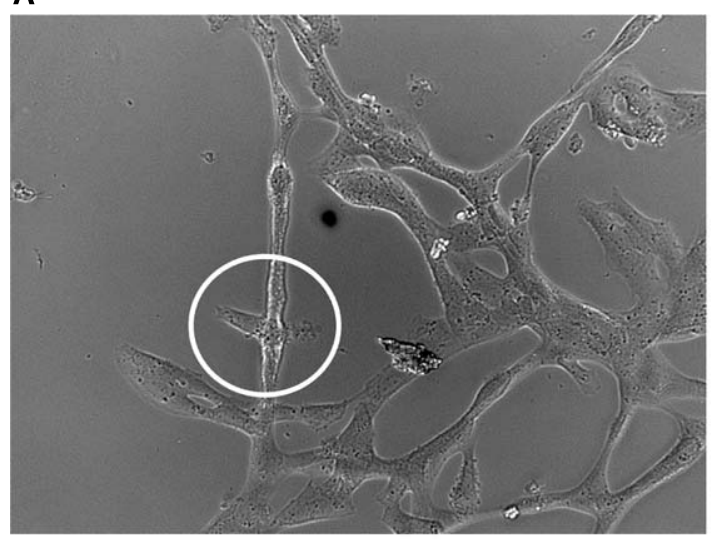

C

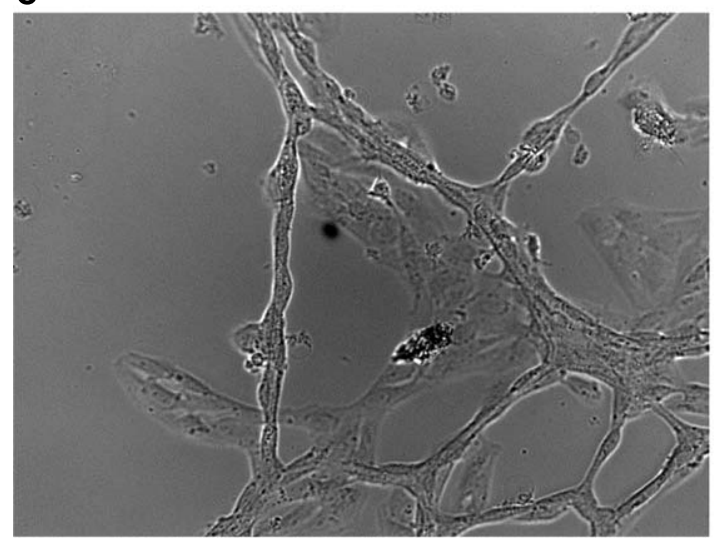

B

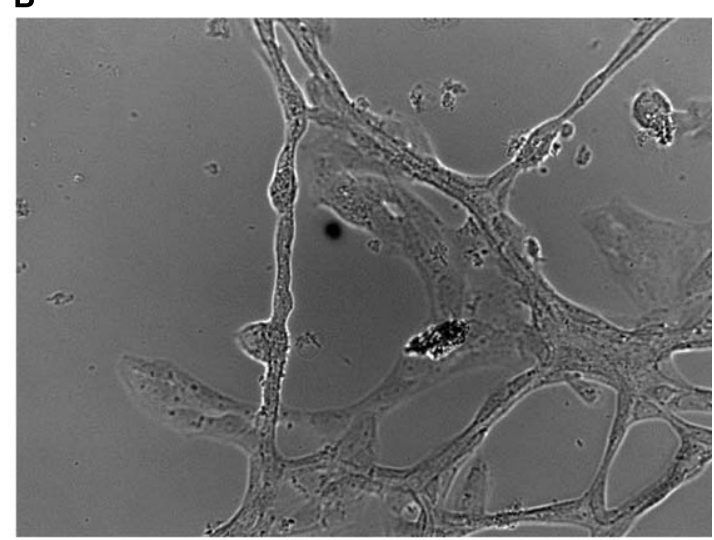

D

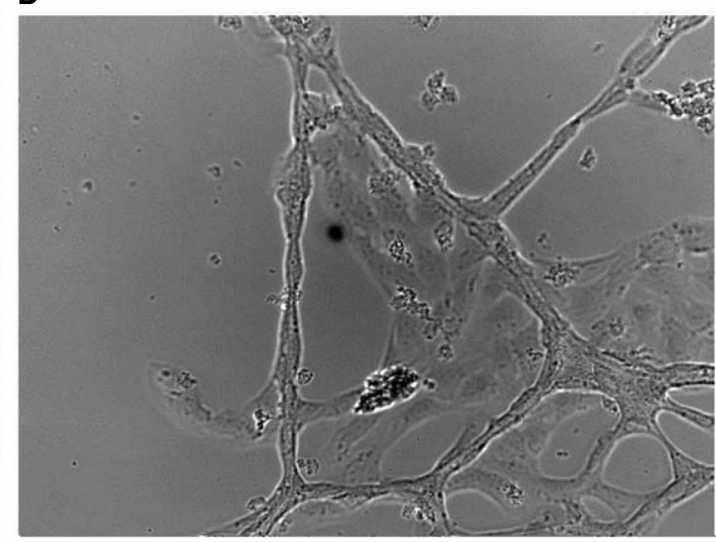

Fig. 9. Life cell imaging: sequence of primary equine endothelial cells in vitro after 28 days in culture; original magnification $200 \times$. (A) Single elongated cell (from left) contacts existing cellular strand ( 0 minutes). (B) The formerly elongated cell changes to a roundish shape upon contact (after 25 minutes). (C) At the point of intercellular contact microparticles are released into the extracellular space. The released material consists of a group of vesicles of different size, floating into the culture medium (after 216 minutes). (D) Finally, the cell is integrated into the three-dimensional capillary like network (after $1782 \mathrm{~min}$ ).

cluster, moved through it, and then once again led the formation of another new vascular sprout. Gradually a homogenous monolayer of polygonal to longish cells was formed.

Stage 3 and 4 of the angiogenesis cascade in vitro (life cell monitoring started on the 28th culturing day): In this monolayer, certain cells became prominent and formed cellular strands by distinct elongation and linear arrangement, while most of the other cells still were in a polygonal state. Eventually, the single cell strands developed into two stranded structures with translucent extracellular material between and around them. In certain areas of the monolayer these elongated cells developed fine protrusions superimposing the monolayer (Fig. 9A). Cells from the bottom of the culture plate integrated themselves into the cellular strands (after 2.5 hours, Fig. 9B). These cells were either located in the monolayer next to an existing strand or they migrated up to several micrometers towards the strand by pseudopodia. Upon contact with the strands, they regained a polygonal to roundish form. During this process, cellular material was released into the extracellular space (after 216, Fig. 9C). This material consisted of microparticles. Most of these were round vesicles of fairly homogenous size, only a few resembled irregularly shaped 
cellular fragments. The extracellular material was suspended in the culture medium. The more cells were integrated into the cell-strands, the fewer cells remained adhering to the culture dish until finally most of the cells were forming a three-dimensional capillary like network (after 29.7 hours $=1782$ minutes, Fig. 9D).

\subsection{Documentation of cellular proliferation and vascular development in different media}

Cells were cultivated in media supplied with a) conventional fetal bovine serum (FBS) plus S180or without S180-conditioned medium or b) species-specific equine serum (fetal horse serum, FHS) with S180- or without S180-conditioned medium. Cells grew readily in either medium, with the cells cultivated with unconditioned FHS forming a confluent monolayer around two days later than the other cultures.

\subsection{Cells from horse with inflammatory processes}

The sample obtained from the nine-month old horse, which suffered from inflammatory processes prior to euthanasia (inflammation of the left stifle, phlegmona of the right tarsus) displayed the poorest proliferation rate. At that point in time when the primary cultures from clinically healthy horses represented a subconfluent monolayer with thousands of cells, only around 50 cells were proliferating in this sample. After seven days, these cells stopped proliferating.

\section{Discussion}

Objective of this study was to develop an in vitro model that allows for evaluating morphology and angiogenesis of primary equine endothelial cell line cultures. Thus, equine endothelial cells from the carotid artery and jugular vein were isolated, identified, cultivated in vitro, and the different stages of the angiogenesis cascade were characterized in these cell cultures including life cell technique. This study presents the first in vitro angiogenesis assay of equine endothelial cells. In the past, equine endothelial cells were isolated from the aorta [51, 82], pulmonary artery [51, 56, 82], umbilical vein [22], fatty omentum [16], carotid artery [13,37], or brain [37]. These cultures were used in studies focusing on clinical aspects related to viral infections or endotoxemia without addressing the angiogenesis cascade.

\subsection{Identification and characterization of equine endothelial cells in vitro}

The Achilles' heel during the establishment of endothelial cell cultures is the contamination with non-endothelial cells. Different methods are recommended to obtain pure cultures including antibody supported sorting of cultures with fluorescence activated or magnetic bead cell sorting $[15,58]$. In our laboratory, endothelial cultures from micro- and macrovascular vessels of different species (bovine, porcine, equine, murine, simian, human), developmental stages (fetal, neonatal, adult), or organs and tissues (testes, ovary, corpus luteum, brain, heart, spleen, lung, skin, foreskin, limb, tumor) [e.g., 10, 11, $41,47,48,64,74,77]$ have been established and different methods have been used including a FACS+ cell sorter. A reliable, inexpensive, and standardized combination of methods used in the present study resulted in pure cultures of macrovascular endothelial cells, which can be established in any laboratory with routine cell culture equipment. 
The experimental setup employed here was focused on using optimal coating of the culture dishes, effective supplementation of the medium, separation of cells that displayed quick adherence, and analysis of the cell morphology. Another focal point was the confirmation of cellular identity by immunolabelling with the specific marker anti-vWF and ultrastructural demonstration of the presence of endothelial marker organelles, i.e. Weibel Palade bodies.

In order to selectively support the growth of the endothelial cells, gelatin was used for coating the culture dishes. Gelatin contains amino acids and proteins, similar to those of the basement membrane, which corresponds to the natural environment of endothelial cells [5]. In our experience, gelatin coating is particularly favorable, since endothelial cells immediately adhere to it and thus to the bottom of the culture wells. Gelatin has been used successfully since the onset of endothelial cell isolation $[50,78,86]$. In contrast to Matrigel, which is frequently used to coat culture dishes in order to activate endothelial angiogenesis, gelatin is derived from clinically healthy animals, whereas Matrigel is the product of tumor cells [e.g., 44]. Other authors describe the usage of different substrates such as purified collagen [61] or fibronectin [24] for coating. Relou et al. [67] did not find significant changes in the growth of human umbilical vein endothelial cells after coating the culture dishes with gelatin, fibronectin, or collagen.

Proliferation of endothelial cells is supported selectively by incubation in primary medium, which contains a combination of growth factors for endothelial cells supporting their proliferation from day 1 . In our study, $\mathrm{P}^{0}$ medium containing mouse $\mathrm{S} 180$ sarcoma cells conditioned medium was used, which has been reported to upregulate endothelial cell expression of basic fibroblast growth factor [75]. Contrary to our expectations, media supplemented with fetal horse serum (FHS) did not increase endothelial proliferation. Both FHS and FBS have been described as suitable supplement to culture medium for equine endothelial cells [51]. However, for different applications species-specific serum has been recommended For example, Zakrzewski et al. [90] described that species-specific serum allowed for better results than FBS when cultivating porcine intestinal cells. Our results are corroborated by Mitchell et al. [59] who in 1969 had already described the superiority of FBS for the selection of cell variants and as best adapted for continuous cell growth in vitro.

The endothelial cells were selected on the basis of their distinct adhesiveness to the gelatin precoated culture plates as compared to other cells. In contrast to non-endothelial cells, endothelial cells show an extraordinary adherence to the coating of the culture dish [e.g., 78]. Thus, slowly adhesive cells were washed away with the supernatant on the first rinsing two hours after the primary seeding. In our study, only the cells adhering quickly, i.e. within 2 hours, were expanded and used for further processing. Navone et al. [61] also used this method successfully to identify and characterize endothelial isolations.

Contamination with non-endothelial cells is a common problem in primary endothelial cell cultures. In our experience, rapid proliferation rate with multilayered growth points towards the presence of nonendothelial cells. Nevertheless, identification of the cells on a morphological basis and by light microscopy only is not feasible. For this reason, endothelial specific markers are necessary to identify these cells. Specific endothelial markers include vWF and the ultrastructural detection of Weibel Palade bodies $[87,88]$. vWF is stored within Weibel-Palade bodies (WPBs), organelles that appear exclusively in endothelial cells. In this study, $100 \%$ of the cells of passage 3 were positive for vWF labeling, which strongly corroborates their endothelial specific character. Labeling became less distinct with extended time in culture, but still was clearly present. Fading and even loss of labeling for vWF has been described for other endothelial cultures including equine endothelial cells and is a frequent effect of long term culturing, indicating a progressive loss of the endothelial phenotype after prolonged time of culture and increased passages $[13,56]$. It is a well-known fact that cells in vitro both gain and lose attributes 
found in vivo. Since it is generally not feasible to use truly primary (not passaged) endothelial cells in angiogenesis assays [6], cell lines derived from primary cultures as presented here may be optimal for the characterization of angiogenesis.

In addition, endothelial nature of the isolated cells was confirmed by the presence of Weibel Palade bodies. These organelles are elongated secretory organelles specific to endothelial cells contributing to inflammation, angiogenesis, and tissue repair [83]. They have been described in most vertebrates including humans [e.g., 43, 87], pigs [34, 72], rats [18], rabbits [14, 68], pigeons [65], fish [89], and amphibians [79].

\subsection{Development and morphology of capillary-like structures of equine endothelial cells in vitro}

In general, there are two pathways leading to the formation of blood vessels: vasculogenesis and angiogenesis [e.g., 62, 63, 69, 70]. Vasculogenesis corresponds to the de novo formation of primitive vascular networks from endothelial progenitor cells, which differentiate into endothelial cells. In contrast, angiogenesis refers to the sprouting and splitting of existing blood vessels by activation, proliferation, and migration of endothelial cells. In vivo, this process is present in physiological, pathophysiological or pathological processes and is induced by certain signal proteins, such as vascular endothelial growth factors or fibroblast growth factors [e.g., 8, 28, 33, 81]. The angiogenic cascade of endothelial cells in vitro has been classified and quantified for bovine [8,9], human [55], and murine [55] endothelium into the following stages: stage 0: proliferation of endothelial cells; stage 1: subconfluent to confluent monolayer of endothelial cells; stage 2: linear and circular side by side arrangement of endothelial cells; stage 3: formation of planar capillary-like structures with an internal lumen; stage 4: formation of a three-dimensional network of capillary-like structure [55]. These stages of the angiogenic cascade could clearly be identified in the equine cultures presented here and confirms the applicability of the cultures in angiogenesis assays.

\subsection{Life-cell imaging and tracking of individual cells in vitro}

In addition to inverted light microscopy life cell imaging was used to characterize endothelial proliferation and in vitro angiogenesis. This allowed for tracking of living endothelial cells in the course of time and the identification of different subpopulations of endothelial cells. To date only few studies are available employing life cell imaging in angiogenesis research [e.g, 4, 54].

Sprouting of single cells out of the monolayer could be documented. These specialized endothelial cells that lead the new sprout at the front are called tip cells [19]. Tip cells have been observed in various models of sprouting angiogenesis [e.g., 31, 46]. Key features of the tip cell are their location at the forefront of endothelial branches, numerous filopodia, the lack of lumen formation, and minimal proliferation [27]. Endothelial tip cells are selected from a quiescent vessel by stimulation due to angiogenic factors in the course of vessel branching or pathological processes and are followed by stalk cells [20]. However, tip and stalk cells change positions frequently during sprouting [e.g., 24, 46]. In this context, the following feature observed here may be relevant: Certain tip cells reversed their forward movement, returned to the cell cluster, moved through the whole length of the cluster, and then once again led the formation of another new vascular sprout. This compares to the results of Li and Stuhlmann [54] who described that endothelial cells moved backwards and forwards, and even overtook each other at the tip, displaying an unknown mode of collective cell movement with dynamic 'cell-mixing'. Thus, we assume that this specific and highly migratory subpopulation of tip cells as seen in equine endothelial cultures may contribute in the resolution 
of thromboses by building vascular channels into fibrin clots. Their malfunction after mechanical or chemical manipulation might be the reason for arterial or venous thrombosis and thrombophlebitis [2].

After single cell strands of equine endothelial cells had developed into two stranded structures, translucent, extracellular material was found to be present between and around them resembling a basement membrane. This corroborates the realistic nature of the equine angiogenesis model presented here. Endothelial cells produce their extracellular matrix and basement membrane in vivo [39, 84]. Sacharidou et al. [73] described that endothelial cells depend on vascular guidance tunnels, which are generated by extracellular matrix. This eventually leads to vascular basement membrane matrix assembly, which in turn is essential to tube maturation and stabilization in order to form capillary networks [25].

Equine endothelial cells released microparticles into the extracellular space. These are defined as particles ranging from $100 \mathrm{~nm}$ to $1 \mu \mathrm{m}$ in diameter. They are released from the plasma membrane of cells by outward budding of membrane vesicles. Studies suggest that the release of microparticles is a highly regulated process that occurs in a spectrum of cell types including endothelial cells. Microparticles have been detected in many various biological fluids, including peripheral blood and urine [76].

Exocytosis of microparticles is an important step in a multitude of different cellular events such as coagulation [29] or cytokine secretion [66]. Early on, Wagner \& Robinson [85] showed three-dimensional conformation and interaction of vesicles with the endothelial surface in endothelium of muscular tissue by high-voltage electron miscroscopy. The function of these vesicles was not known.

Recently, Sacharidou et al. [73] described vacuoles, i.e. intracellular microparticle-like organelles in the context of lumen formation of human umbilical vein endothelial cells. Endothelial vacuoles undergo both intracellular fusion and exocytic fusion events with plasma membranes. Moreover, other intracellular organelles, such as Weibel-Palade bodies, appear to fuse with intracellular vacuoles and transfer their contents in order to rapidly create fluid-filled apical membranes and form early luminal structures. Davis et al. [26] also described intracellular vacuoles targeting the apical surface, which are involved in polarization of the endothelial cells during lumen formation. In the equine cultures established here, microparticles were released from endothelial cells at the time of their integration from the monolayer into the three-dimensional capillary-like structures. This step is related to an apparent change in the morphology of endothelial cells and indicates a novel functional role within the cellular network. Moreover, Shai and Varon [76] describe in their recent review that microparticles had been considered inert cell debris, but increasing evidence suggests that they are involved in intercellular communication, including angiogenesis. Correspondingly, microparticles of equine cultures may adopt various functions during the phases of angiogenesis. However, their exact role still has to be clarified.

In conclusion, the assay presented here can be used as a model to monitor the steps of angiogenesis starting from endothelial cell proliferation to the formation of a three-dimensional capillary-like structure. Moreover, this assay allows for in vitro studies of endothelial pathophysiology, particularly the reaction of endothelial cells to mechanical or chemical interventions. It is widely accepted that equine vessels are more sensitive to manipulation as compared to those of other species, which often results in thrombophlebitis or loss of function $[30,36,52]$. Future studies will target effects of mechanical or chemical lesions on the equine angiogenic cascade in vitro with emphasis on microparticles and the specific population of tip cells described above which we suspect to malfunction during thrombolysis.

\section{Acknowledgments}

The authors would like to thank Karin Briest-Forch and Monika Sachtleben for their excellent technical expertise, and Verena Holle and Martin Werner for competent preparation of figures. 


\section{References}

[1] S. Alias and I.M. Lang, Coagulation and the vessel wall in pulmonary embolism, Pulm Circ 3 (2013), 728-738.

[2] S. Alias, B. Redwan, A. Panzenböck, M.P. Winter, U. Schubert, R. Voswinckel, M.K. Frey, J. Jakowitsch, A. Alimohammadi, L. Hobohm, A. Mangold, H. Bergmeister, M. Sibilia, E.F. Wagner, E. Mayer, W. Klepetko, T.J. Hölzenbein, K.T. Preissner and I.M. Lang, Defective angiogenesis delays thrombus resolution: A potential pathogenetic mechanism underlying chronic thromboembolic pulmonary hypertension, Arterioscler Thromb Vasc Biol 34 (2014), 810-819.

[3] A. Andras and B. Ferket, Screening for peripheral arterial disease, Cochrane Database Syst Rev (2014) 4, CD010835. DOI: 10.1002/14651858.CD010835.pub2

[4] S. Arima, K. Nishiyama, T. Ko, Y. Arima, Y. Hakozaki, K. Sugihara, H. Koseki, Y. Uchijima, Y. Kurihara and H. Kurihara, Angiogenic morphogenesis driven by dynamic and heterogeneous collective endothelial cell movement, Development 138 (2011), 4763-4776.

[5] Y. Asano, A. Nishiguchi, M. Matsusaki, D. Okano, E. Saito, M. Akashi and H. Shimoda, Ultrastructure of blood and lymphatic vascular networks in three-dimensional cultured tissues fabricated by extracellular matrix nanofilm-based cell accumulation technique, Microscopy (2014), 219-226.

[6] A.G. Atici, S. Kayhan, D. Aydin and Y.A. Yilmaz, Plasma viscosity levels in pulmonary thromboembolism, Clin Hemorheol Microcirc 55 (2013), 313-320.

[7] R. Auerbach, R. Lewis, B. Shinners, L. Kubai and N. Akhtar, Angiogenesis assays: A critical overview, Clin Chem 49(1) (2003), 32-40.

[8] M. Bahramsoltani, W. de Spiegelaere, P. Janczyk, B. Hiebl, P. Cornillie and J. Plendl, Quantitation of angiogenesis in vitro induced by VEGF-A and FGF-2 in two different human endothelial cultures - an all-in-one assay, Clin Hemorheol Microcirc 46 (2010), 189-202.

[9] M. Bahramsoltani and J. Plendl, Ein neues in vitro-Modell zur Quantifizierung der Angiogenese, Altex 21 (2004), 227-244.

[10] M. Bahramsoltani, J. Plendl, P. Janczyk, P. Custodis and S. Käßmeyer, Quantitation of Angiogenesis and Antiangiogenesis in vivo, ex vivo and in vitro - an overview, Altex 26 (2009), 95-107.

[11] M. Bahramsoltani, I. Slosarek, W. de Spiegelaere and J. Plendl, Angiogenesis and collagen type IV expression in different endothelial cell culture systems, Anat Histol Embryol 43 (2014), 103-115.

[12] J. Beinsberger, J.W. Heemskerk and J.M. Cosemans, Chronic arthritis and cardiovascular disease: Altered blood parameters give rise to a prothrombotic propensity, Semin Arthritis Rheum (2014), DOI: 10.1016/j.semarthrit.2014.06.006

[13] H. Benbarek, S. Grülke, G. Deby-Dupont, C. Deby, M. Mathy-Hartert, I. Caudron, C. Dessy-Doize, M. Lamy and D. Serteyn, Cytotoxicity of stimulated equine neutrophils on equine endothelial cells in culture, Equine Vet J 32 (2000), 327-333.

[14] F. Bierring and T. Kobayashi, Electron microscopy of the normal rabbit aorta, Acta Pathol Microbiol Scand 57 (1963), $154-168$.

[15] W.A. Bonner, H.R. Hulett, R.G. Sweet and L.A. Herzenberg, Fluorescence activated cell sorting, Rev Sci Instrum 43(3) (1972), 404-409.

[16] P.N. Bochsler, D.O. Slauson, S.K. Chandler and M.M. Suyemoto, Isolation and characterization of equine microvascular endothelial cells in vitro, Am J Vet Res 50 (1989), 1800-1805.

[17] P. Brianceau and T.J. Divers, Acute thrombosis of limb arteries in horses with sepsis: Five cases (1988-1998), Equine Vet $J 33$ (2001), 105-109.

[18] P.H. Burri and E.R. Weibel, Beeinflussung einer spezifischen cytoplasmatischen Organelle von Endothelzellen durch Adrenalin, Z Zellforsch 88 (1970), 426-440.

[19] P. Carmeliet, P., F. de Smet, S. Loges and M. Mazzone, Branching morphogenesis and antiangiogenesis candidates: Tip cells lead the way, Nat Rev Clin Oncol 6 (2009), 315-326.

[20] P. Carmeliet and R.K. Jain, Molecular mechanisms and clinical applications of angiogenesis, Nature 473(7347) (2011), 298-307.

[21] J. Castle, H. Shaker, K. Morris, J.D. Tugwood and C.C. Kirwan, The significance of circulating tumour cells in breast cancer: A review, Breast (2014).

[22] R. Chiam, L. Smid, J.H. Kydd, K.C. Smith, A. Platt and N.J. Davis-Poynter, Use of polarised equine endothelial cell cultures and an in vitro thrombosis model for potential characterisation of EHV-1 strain variation, Vet Microbiol 113 (2006), 243-249. 
[23] J.J. Chiu and S. Chien, Effects of disturbed flow on vascular endothelium: Pathophysiological basis and clinical perspectives, Physiol Rev 91 (2011), 327-387.

[24] C.K. Choi and C.S. Chen, Jostling for position in angiogenic sprouts: Continuous rearrangement of cells explained by differential adhesion dynamics, Embo J (2014).

[25] G.E. Davis, K.J. Bayless and A. Mavila, Molecular basis of endothelial cell morphogenesis in three-dimensional extracellular matrices, Anat Rec 268(3) (2002), 252-275.

[26] G.E. Davis, A.N. Stratman, A. Sacharidou and W. Koh, Molecular basis for endothelial lumen formation and tubulogenesis during vasculogenesis and angiogenic sprouting, Int Rev Cell Mol Biol 288 (2011), 101-165.

[27] F. de Smet, I. Segura, K. De Bock, P.J. Hohensinner and P. Carmeliet, Mechanisms of vessel branching filopodia on endothelial tip cells lead the way, Arterioscl Throm Vas 29(5) (2009), 639-649.

[28] W. de Spiegelaere, C. Casteleyn, W. van den Broeck, J. Plendl, M. Bahramsoltani, P. Simoens, V. Djonov and P. Cornillie, Intussusceptive angiogenesis: A biologically relevant form of angiogenesis, J Vasc Res 49 (2012), 390-404.

[29] M. Diamant, M.E. Tushuizen, A. Sturk and R. Nieuwland, Cellular microparticles: New players in the field of vascular disease? Eur J Clin Invest 34(6) (2004), 392-401.

[30] B.A. Dolente, J. Beech, S. Lindborg and G. Smith, Evaluation of risk factors for development of catheter-associated jugular thrombophlebitis in horses: 50 cases (1993-1998), J Am Vet Med Assoc 227 (2005), 1134-1141.

[31] H.M. Eilken and R.H. Adams, Dynamics of endothelial cell behavior in sprouting angiogenesis, Curr Opin Cell Biol 22(5) (2010), 617-625.

[32] K.L. Epstein, Coagulopathies in Horses, Vet Clin North Am Equine Pract 30 (2014), 437-452.

[33] N. Ferrara, Role of vascular endothelial growth factor in physiologic and pathologic angiogenesis: Therapeutic implications, Semin Oncol 29 (2002), 10-14.

[34] J. Gebrane-Younes, L. Drouet and J.P. Caen, Weibel-Palade bodies in pig megakaryocytes, Biol Struct Morphog 1 (1988), $58-62$.

[35] H. Gehlen and P. Stadler, Gefäßerkrankungen. Pferdekardiologie, in: H. Gehlen, ed., Schlütersche, 1. Auflage, Hannover, 2009, pp. 191-206.

[36] T.E. Geraghty, S. Love, D.J. Taylor, J. Heller, D.J. Mellor and K.J. Hughes, Assessment of subclinical venous catheter-related diseases in horses and associated risk factors, Vet Rec 164 (2009), 227-231.

[37] L.S. Goehring, G.S. Hussey, L.V. Ashton, A.R. Schenkel and D.P. Lunn, Infection of central nervous system endothelial cells by cell-associated EHV-1, Vet Microbiol 148 (2011), 389-395.

[38] L.E. Gordon, P.E. Danielsson, T.S. Nguyen and H.R. Winn, A comparison of primary cultures of rat cerebral microvascular endothelial cells to rat aortic endothelial cells, In Vitro Cell Dev Biol 27(4) (1991), 312-326.

[39] D.S. Grant and H.K. Kleinman, Regulation of capillary formation by laminin and other components of the extracellular matrix. In Regulation of Angiogenesis, Birkhäuser, Basel, 1997, 317-333.

[40] A.T. Hirsch, L. Hartman, R.J. Town and B.A. Virnig, National health care costs of peripheral arterial disease in the Medicare population, Vasc Med 13 (2008), 209-215.

[41] R.M. Hirschberg and J. Plendl, Pododermal angiogenesis and angioadaptation in the bovine claw, Microsc Res Tech 66 (2005), 145-155.

[42] L.W. Hoyer, R.P. de los Santos and J.R. Hoyer, Antihemophilic factor antigen. Localization in endothelial cells by immunofluorescent microscopy, J Clin Invest 52(11) (1973), 2737-2744.

[43] R.H. Huang, Y. Wang, R. Roth, X. Yu, A.R. Purvis, J.E. Heuser, E.H. Egelman and J.E. Sadler, Assembly of Weibel-Palade body-like tubules from N-terminal domains of von Willebrand factor, Proc Natl Acad Sci 105 (2008), 482-487.

[44] C.S. Hughes, L.M. Postovit and G.A. Lajoie, Matrigel: A complex protein mixture required for optimal growth of cell culture, Proteomics 10 (2010), 1886-1890.

[45] E.A. Jaffe, R.L. Nachman, C.G. Becker and C.R. Minick, Culture of human endothelial cells derived from umbilical veins. Identification by morphologic and immunologic criteria, J Clin Invest 52(11) (1973), 2745-2756.

[46] L. Jakobsson, C.A. Franco, K. Bentley, R.T. Collins, B. Ponsioen, I.M. Aspalter and H. Gerhardt, Endothelial cells dynamically compete for the tip cell position during angiogenic sprouting, Nat Cell Biol 12(10) (2010), 943-953.

[47] D.S. Kaufman, R.L. Lewis, E.T. Hanson, R. Auerbach, J. Plendl and J.A. Thomson, Functional endothelial cells derived from rhesus monkey embryonic stem cells, Blood 103 (2004), 1325-1332.

[48] S. Käßmeyer, K. Bhoola, S. Baltic, P. Thompson and J. Plendl, Lung cancer neovascularisation: Cellular and molecular interaction between endothelial and lung cancer cells, Immunobiology 219 (2014), 308-314.

[49] F.J. Kim, A. Campagna, L. Khandrika, S. Koul, S.S. Byun, A.V. Bokhoven and H. Koul, Individualized medicine for renal cell carcinoma: Establishment of primary cell line culture from surgical specimens, J Endourol 22(10) (2008), 2361-2366. 
[50] N.S. Kim and S.J. Kim, Isolation and cultivation of microvascular endothelial cells from rat lungs: Effects of gelatin substratum and serum, Yonsei Med J 32 (1991), 303-314.

[51] C.H. Lamar, J.J. Turek, G.D. Bottoms and J.F. Fessler, Equine endothelial cells in vitro, Am J Vet Res 47 (1986), $956-958$.

[52] D.P. Lankveld, J.M. Ensink, P. van Dijk and W.R. Klein, Factors influencing the occurrence of thrombophlebitis after post-surgical long-term intravenous catheterization of colic horses: A study of 38 cases, J Vet Med A Physiol Pathol Clin Med 48 (2001), 545-552.

[53] M. Levi, H. ten Cate and T. van der Poll, Endothelium: Interface between coagulation and inflammation, Crit Care Med 30 (2002), S220-S224

[54] J. Li and H. Stuhlmann, In vitro imaging of angiogenesis using embryonic stem cell-derived endothelial cells, Stem Cells Dev 21(2) (2011), 331-342.

[55] J. Lienau, C. Kaletta, M. Teifel, K. Naujoks, K. Bhoola and J. Plendl, Morphology and transfection study of human microvascular endothelial cell angiogenesis: An in vitro three-dimensional model, Biol Chem 386 (2005), 167-175.

[56] K.E. MacEachern, G.L. Smith and A.M. Nolan, Methods for the isolation, culture and characterization of equine pulmonary artery endothelial cells, Res vet Sci 62 (1997), 147-152.

[57] M. Millrose, M. Kruse, B. Flick and R. Stahlmann, Effects of macrolides on proinflammatory epitopes on endothelial cells in vitro, Arch Toxicol 83 (2009), 469-476.

[58] S. Miltenyi, W. Müller, W. Weichel and A. Radbruch, High gradient magnetic cell separation with MACS, Cytometry 11(2) (1990), 231-238.

[59] J.T. Mitchell, W.F. Andresen and V.J. Evans, Comparative effects of horse, calf, and fetal serums on chromosomal characteristics and neoplastic conversion of mouse embryo cells in vitro, J Natl Cancer Inst 42 (1969), 709-721.

[60] B. Modarai, K.G. Burnand, J. Humphries, M. Waltham and A. Smith, The role of neovascularisation in the resolution of venous thrombus, Thromb Haemost 93 (2005), 801-809.

[61] S.E. Navone, G. Marfia, G. Invernici, S. Cristini, S. Nava, S. Balbi, S. Sangiorgi, E. Ciusani, A. Bosutti, G. Alessandri, M. Slevin and E.A. Parati, Isolation and expansion of human and mouse brain microvascular endothelial cells, Nat Protoc 8(9) (2013), 1680-1693.

[62] S. Patan, TIE1 and TIE2 receptor tyrosine kinases inversely regulate embryonic angiogenesis by the mechanism of intussusceptive microvascular growth, Microvasc Res 56 (1998), 1-21.

[63] S. Patan, Vasculogenesis and angiogenesis, Cancer Treat Res 117 (2004), 3-32.

[64] J. Plendl, C. Neumüller, A. Vollmar, R. Auerbach and F. Sinowatz, Isolation and characterization of endothelial cells from different organs of fetal pigs, Anat Embryol 194 (1996), 445-456.

[65] E. Raviola and G. Raviola, A light and electron microscopic study of the pecten of the pigeon eye, Am J Anat 120 (1967), $427-461$.

[66] V.L. Reid and N.R. Webster, Role of microparticles in sepsis, Brit J Anaesth 109(4) (2012), 503-513.

[67] I.A. Relou, C.A. Damen, D.W. van der Schaft, G. Groenewegen and A.W. Griffioen, Effect of culture conditions on endothelial cell growth and responsiveness, Tissue Cell 30(5) (1998), 525-530.

[68] J.A. Rhodin, Ultrastructure of mammalian venous capillaries, venules, and small collecting veins, J Ultrastruct Res 25 (1968), 452-500.

[69] W. Risau, Vasculogenesis, angiogenesis and endothelial cell differentiation during embryonic development in: The Development of the Vascular System, R.N. Feinberg, G.K. Sherer and R. Auerbach, eds., Issues Biomed, Karger, Basel, vol 14, (1991), 58-68.

[70] W. Risau, Mechanisms of angiogenesis, Nature 386 (1997), 671-674.

[71] B. Romeis, Romeis Mikroskopische Technik (microscopic techniques), 18 ed., M. Mulisch and U. Welsch, eds., Spektrum Akademischer Verlag, Berlin, 2010.

[72] T. Royo, J. Martínez-González, G. Vilahur and L. Badimon, Differential intracellular trafficking of von Willebrand factor (vWF) and vWF propeptide in porcine endothelial cells lacking Weibel-Palade bodies and in human endothelial cells, Atherosclerosis 167 (2003), 55-63.

[73] A. Sacharidou, A.N. Stratman and G.E. Davis, Molecular mechanisms controlling vascular lumen formation in threedimensional extracellular matrices, Cells Tissues Organs 195 (2012), 122-143.

[74] K. Schoen, R.M. Hirschberg, J. Plendl and S. Kaessmeyer, Identification of CD133-, CD34- and KDR-positive cells in the bovine ovary: A new site of vascular wall resident endothelial progenitor cells, Clin Hemorheol Microcirc 52 (2012), 67-84.

[75] G. Seghezzi, R. Marelli, S.J. Mandriota, M.L. Nolli, R. Mazzieri and P. Mignatti, Tumor cell-conditioned medium stimulates expression of the urokinase receptor in vascular endothelial cells, J Cell Physiol 169 (1996), 300-308. 
[76] E. Shai and D. Varon, Development, cell differentiation, angiogenesis-microparticles and their roles in angiogenesis, Arterioscl Thromb Vasc Biol 31(1) (2011), 10-14.

[77] H. Sievers, M. Bahramsoltani, S. Käßmeyer and J. Plendl, In vitro angiogenic potency in human microvascular endothelial cells derived from myocardium, lung and skin, Clin Hemorheol Microcirc 49 (2011), 473-486.

[78] M. Sobczak, J. Dargatz and M. Chrzanowska-Wodnicka, Isolation and culture of pulmonary endothelial cells from neonatal mice, $J$ Vis Exp 46 (2010), e2316, DOI: 10.3791/2316

[79] K.F. Steinsiepe and E.R. Weibel, Elektronenmikroskopische Untersuchungen an spezifischen Organellen von Endothelzellen des Frosches (Rana temporaria), Z Zellforsch 108 (1970), 105-126.

[80] D.J. Stephens and V.J. Allan, Light microscopy techniques for live cell imaging, Science 300(5616) (2003), 82-86.

[81] G. Szebenyi and J.F. Fallon, Fibroblast growth factors as multifunctional signaling factors, Int Rev Cytol 185 (1999), 45-106.

[82] J.J. Turek, C.H. Lamar, J.F. Fessler and G.D. Bottoms, Ultrastructure of equine endothelial cells exposed to endotoxin and flunixin meglumine and equine neutrophils, Am J Vet Res 48 (1987), 1363-1366.

[83] K.M. Valentijn, J.E. Sadler, J.A. Valentijn, J. Voorberg and J. Eikenboom, Functional architecture of Weibel-Palade bodies, Blood 117 (2011), 5033-5043.

[84] R.B. Vernon and E.H. Sage, Between molecules and morphology. Extracellular matrix and creation of vascular form, $A m$ J Pathol 147(4) (1995), 873-883.

[85] R.C. Wagner and C.S. Robinson, High-voltage electron microscopy of capillary endothelial vesicles, Microvasc Res 28(2) (1984), 197-205.

[86] S.C. Weber, A. Gratopp, S. Akanbi, C. Rheinlaender, H. Sallmon, P. Barikbin and P.S. Koehne, Isolation and culture of fibroblasts, vascular smooth muscle, and endothelial cells from the fetal rat ductus arteriosus, Pediatr Res 70 (2011), 236-241.

[87] E.R. Weibel and G.E. Palade, New cytoplasmic components in arterial endothelia, J Cell Biol 23 (1964), 101-112.

[88] E.R. Weibel, Fifty years of Weibel-Palade bodies: The discovery and early history of an enigmatic organelle of endothelial cells, J Throm Haemost 10 (2012), 979-984.

[89] K. Yano, D. Gale, S. Massberg, P.K. Cheruvu, R. Monahan-Earley, E.S. Morgan, D. Haig, U.H. von Andrian, A.M. Dvorak and W.C. Aird, Phenotypic heterogeneity is an evolutionarily conserved feature of the endothelium, Blood 109 (2007), 613-615.

[90] S.S. Zakrzewski, J.F. Richter, S.M. Krug, B. Jebautzke, I.-F.M. Lee, J. Rieger, M. Sachtleben, A. Bondzio, J.D. Schulzke, M. Fromm and D. Günzel, Improved cell line IPEC-J2, characterized as a model for porcine jejunal epithelium, PLoS ONE 8 (2013), e79643. 